\title{
AN INTEGRATED ECONOMETRIC MODEL FOR BUS REPLACEMENT AND DETERMINATION OF RESERVE FLEET SIZE BASED ON PREDICTIVE MAINTENANCE
}

\section{ZINTEGROWANY EKONOMETRYCZNY MODEL DO MODELOWANIA WYMIANY TABORU AUTOBUSOWEGO ORAZ OKREŚLANIA WIELKOŚCI FLOTY REZERWOWEJ W OPARCIU O KONSERWACJĘ PREDYKCYJNĄ}

\begin{abstract}
Maintenance policies influence equipment availability and, thus, they affect a company's capacity for productivity and competitiveness. It is important to optimize the Life Cycle Cost (LCC) of assets, in this case, passenger bus fleets. The paper presents a predictive condition monitoring maintenance approach based on engine oil analysis, to assess the potential impact of this variable on the availability of buses. The approach has implications on maintenance costs during the life of a bus and, consequently, on the determination of the best time for bus replacement. The paper provides an overview of economic replacement models through a global model, with an emphasis on availability and its dependence on maintenance and maintenance costs. These factors help to determine the size of the reserve fleet and guarantee availability.
\end{abstract}

Keywords: condition monitoring, LCC, replacement, reserve fleet.

\begin{abstract}
Polityka konserwacji wpływa na gotowość sprzętu, a tym samym na wydajność i konkurencyjność przedsiębiorstwa. Ważne jest optymalizowanie kosztów cyklu życia (LCC) aktywów, w tym przypadku taboru autobusowego. W artykule przedstawiono metode utrzymania ruchu polegająca na predykcyjnym monitorowaniu stanu w oparciu o analize oleju silnikowego w celu oceny potencjalnego wplywu tej zmiennej na gotowość autobusów. Podejście to ma praktyczne konsekwencje jeśli chodzi o koszty utrzymania $w$ trakcie eksploatacji autobusu, a także pozwala na ustalenie najlepszego czasu na wymianę pojazdów taboru. W pracy przedstawiono przeglad ekonomicznych modeli wymiany oraz opracowano model globalny integrujący te modele, ze szczególnym uwzględnieniem gotowości oraz jej zależności od konserwacji oraz kosztów utrzymania ruchu. Czynniki te pomagają określić wielkość floty rezerwowej i zapewnić gotowość taboru.
\end{abstract}

Slowa kluczowe: monitorowanie stanu, koszty cyklu życia, wymiana, flota rezerwowa.

\section{Introduction}

A reserve fleet is defined as the number of vehicles ready to deliver the function for which they were designed, that is, not immobilized by breakdown or planned maintenance, with maximum availability. In transport sector companies, the efficient use of physical assets is linked to a well-structured policy of evaluation and fleet replacement. National and international road transport companies have a wide range of suggested ratios of reserve fleet to total fleet from which to choose. The recommended size of a fleet reserve specified by the US FTA (Federal Transit Administration), in Circular C 1A 90301987 Appendix A, is $20 \%$ of the total number of vehicles [47].

In the passenger transport sector, the determination of the optimum time for bus replacement is related to the efficient use of assets and the company's global or total costs. The company needs to know the right time to replace a bus to reduce its total costs, while still guaranteeing the availability and quality of service and ensuring customer satisfaction. The main objective of this paper is to define a methodology to determine the best cost at the best time to replace a bus.

The value of money is directly linked to time, because the later an asset is withdrawn from service, the greater the action of external agents on it and the greater the influence of macroeconomic factors (i.e., the inflation rate) on its value. This obviously has an effect on transportation costs

The paper discusses the relations between some technical maintenance Key Performance Indicators (KPI's) [42], specifically Mean Time to Repair (MTTR), Mean Time Between Failure (MTBF), Availability (A), and the dimension of the reserve fleet. The Return On Investment (ROI), a financial indicator to assess the equipment's financial performance, is used as a "bridge" between the maintenance and the economic fields, showing us when the equipment starts creating profit or loss to the company. It looks at models to determine the influence of these variables on the withdrawal time and size of the reserve fleet and uses oil analysis as an example of how condition monitoring may influence the availability of the whole bus fleet and the size of the reserve fleet. The paper gives a comprehensive summary of the discussed methodologies, emphasizing the immobilization time caused by maintenance; using a global model, it demonstrates its relevance to the dimensioning of the reserve fleet and the withdrawal time.

\section{State of the art}

Condition Monitoring (CM) represents an approach to preventive maintenance based on knowledge of the equipment's condition determined by monitoring one or several parameters that permit us to 
evaluate the equipment's health [12]. The maintenance of a passenger bus is a strategic activity to maximize its life cycle, involving a combination of management, technical and economic actions to achieve high availability at reasonable costs $[3,6,7,11,31,32]$.

The Life Cycle Cost (LCC) of an asset represents the sum of all capital spent to support it from design and manufacturing, through its operation until the end of its life, (CAPEx+OPEx - Capital Expenditure+Operational Expenditure), [6]. The LCC of an asset can be significantly higher than the value of the initial investment, and is usually defined at the design phase [7]. Bescherer [11] says as much as $70-90 \%$ of the total LCC costs are defined at this stage. To this, Aoudia et al. [3] add that poor maintenance management contributes to a significant increase in LCC.

The initial investment cost is often the only criterion in purchase decisions, notwithstanding the benefits of a LCC approach. Possible reasons include a lack of knowledge of the existing standards or formal guidelines and the absence of reliable past data. There are few cross-case studies in the field of life cycle costing, and most are limited to a single industry, [32]. Korpi and Ala-Risku [31] give an overview of the use of LCC and the feasibility of implementation, through a summary of work on its application.

Simply stated, LCC analysis predicts the future. Several methods can be used to estimate future costs, as, for example, Activity-Based Costing (ABC) [20, 21]. Certain standards, such as those specified in $[8,9]$, support the use of LCC analysis. The rules on asset management given in PAS 55 [28], and in ISO 5500X [8] are good guidelines for physical asset management and can be applied in any sector.

The above points are well known, but there is a lack of systematic study in this area. We need new management models to improve equipment productivity and quality of service, with aspects like environmental sustainability, quality management standards, security, maintenance and energy included in the models [22]. Many companies keep equipment in operation, even when this is no longer economically viable, simply because they do not consider their entire economic cycle [22]. This has implications for many areas, including the size of the reserve fleet.

According to William et al. [52], traditional production systems are built on the principle of the economy of scale. The authors illustrate an equipment replacement problem in the context of Lean Thinking, showing the relevance of econometric models. Jennifer and Joseph [29] refer to technological change as a motivator for equipment replacement; they say technology develops continuously according to a well-defined function. Natalia and Yuri [38] combine discrete and continuous models in time to show that the replacement time for equipment decreases when the technology is more advanced.

According to Assaf [5], "the evaluation of an asset is established by the cash flows expected future benefits referred to the present value by a discount rate that reflects the risk of the decision". Consequently, methods considering the value of money over time are the most suitable to use in replacement decisions. In the view of Casarotto [16], the Annual Cost Uniform Equivalent approach is suitable for the analysis of operational activities of a company with investments that can be repeated. The standardization of investment based on annual equivalent values facilitates the analysis required for decision-making. With this method, it is possible to determine which year has the lowest equivalent annual cost; this, in turn, indicates the best technical replacement period [16]. The calculation of the equivalent annual cost is based on the Capital Recovery Factor. It is possible to compare two or more investment opportunities to determine the best time for equipment replacement, taking into account information such as: acquisition value; maintenance cost; resale value or residual value at the end of each year; operating costs; the cost of capital or the attractive minimum rate [49].
To determine equipment economic life with the objective of finding the most rational replacement time, four situations are applicable [36]:

i When the asset is already unsuitable for work;

ii When the asset has reached its lifespan;

iii When the asset is already obsolete due to technological advances;

iv When there are more efficient and economical solutions.

Some studies also consider the following aspects [22]:

- Availability of new technologies;

- Compliance with safety standards or other mandatory requirements;

- Availability of spare parts;

- Obsolescence that may limit the asset's use.

When the equipment enters the final phase of its LCC, it is important to determine the most rational time to withdrawal it. Several variables are important in such evaluation, including:

- Purchase price of new equipment;

- Withdrawal value;

- Operating costs;

- Maintenance costs;

- Inflation and capitalization rates.

The values of most variables are available in the asset's history, except for the withdrawal value. In this case, it is necessary to know the market value for each specific asset. Unfortunately, the knowledge of this value is difficult for many assets. In such cases, several types of depreciation can be simulated [39]:

- Linear method - devaluation is constant over the years;

- Exponential method - devaluation decreases exponentially over the years;

- Sum of digits method - devaluation is not linear over the years, but is less than exponential.

The evaluation of the equipment economic lifespan is another common method to estimate the withdrawal time: i.e., when the equipment maintenance costs exceed the cost of maintenance plus the capital amortization of new similar equipment. Farinha [22] lists three common ways to determine the economic cycle for equipment replacement:

i Income Annual Uniform Method;

ii Minimizing Total Average Cost Method;

iii Minimizing Total Average Cost Reduced to Present Value Method.

Feldens et al. [23] say the efficient use of physical assets is a main objective of urban passenger transport companies. In the road transport sector, the efficient use of assets is linked to a well-structured policy of fleet evaluation and replacement. Some cases of fleet replacement applied to urban buses are reported in $[10,19,25,30,40$, $43,45,51,55]$. Beichelt [10] proposes a policy for optimal scheduling replacement intervals of technical systems on the basis of a maintenance cost parameter: a system is replaced by a new one as soon as the maintenance cost within a replacement cycle reaches or exceeds a given level. Franck et al. [25] describe an industrial application of a Power Law Process (PLP) and a theoretical replacement model.

Pinar and Hartman [40] adopt a model for a transit fleet replacement problem with multiple types of buses. However, many cost functions are highly simplified or not based on real data, and the authors do not study the variability in vehicular characteristics, usages, and market fluctuations. The cost of replacing, refabricating, and rehabilitating buses is the focus of research by Khasnabis et al. [30]; they also 
consider the optimal allocation proposed by the Federal Transit Administration (FTA). Other lines of research have focused on statistical analyses of fleet data and the relationships among age, utilization, and costs, [19].

Raposo et al. [43] present a new approach to economic models to determine the best time for bus replacement in an urban fleet. The study employs life cycle assessment and a decision support tool. Using the annual uniform income method of analysis, the authors demonstrate there is a variation in the ideal time for bus replacement.

Campos et al. [15] propose a generic model based on a neural stochastic process that can be applied to problems involving data with a stochastic behavior with periodic characteristics. Using neural network models, they model the behavior of an historic data series without requiring a priori information about the series, by generating a synthetic time series adaptable to time series. Some cases of use of neural networks and stochastic models are reported in $[1,4,15,24$, $26,27,33,35,37,50,54]$. Araújo and Bezerra [4] demonstrate the feasibility of a component that implements a stochastic decision support model to integrate with corporate information systems, thus contributing to the efficiency and effectiveness of the decision-making process.

Stochastic models and neural networks are often used in decision support, such as replacement [24] or interventions [35]. Other authors suggest the coordination of maintenance scheduling for the transportation fleets of many branches of a logistic service provider [27], the identification techniques of linear and nonlinear time series [33], the evaluation of vehicle fleet maintenance management indicators [50], and a chaotic time series prediction based on neural networks [54]. For work on neural networks, [15] and [26] are good references.

Other tools may contribute to the development of a new model for the optimization of bus replacement, such as Fuzzy Logic and Support Vector Machine (SVM) [14, 17, 18, 41, 44, 48, 53]. For predictive maintenance, specifically using oil analysis, several mathematical models are appropriate $[2,12,13,22,46]$. Lubricant degradation is not an instantaneous process; the loss of physicochemical properties and contamination are progressive over time and use of equipment, so the lubricant life is limited in service [46]. Algorithms based on exponential smoothing give interesting results [22].

\section{An integrative approach to evaluate reserve fleet}

The next sections present the theoretical models that support our study of the bus fleet reserve and explain their relations to maintenance policies, namely condition monitoring and predictive maintenance. A global view of the approach is the following:

- Econometric models to determine the most rational value of LCC

- Uniform Annual Income, taking into account the following variables:

- Operating costs

- Maintenance costs

- Fuel costs

- Replacement value

- Inflation rate

- Capitalization rate

- Useful life, taking into account the above variables

- Conditioning monitoring / predictive maintenance models to maximize availability

- Reliability KPI's

These approaches are integrated into a single analytical model that allow us to determine the best time for bus withdrawal, that is the time when Uniform Annual Income reaches its lowest value or when the equipment reaches its useful life. The size of the reserve fleet is indexed to the size of the overall fleet.
The integrated approach is valid for both new and used buses through the monetary correction effect. The analysis herein does not include technological and environmental aspects. Figure 3.1 shows the proposed integrative model to determine the size of a reserve fleet.

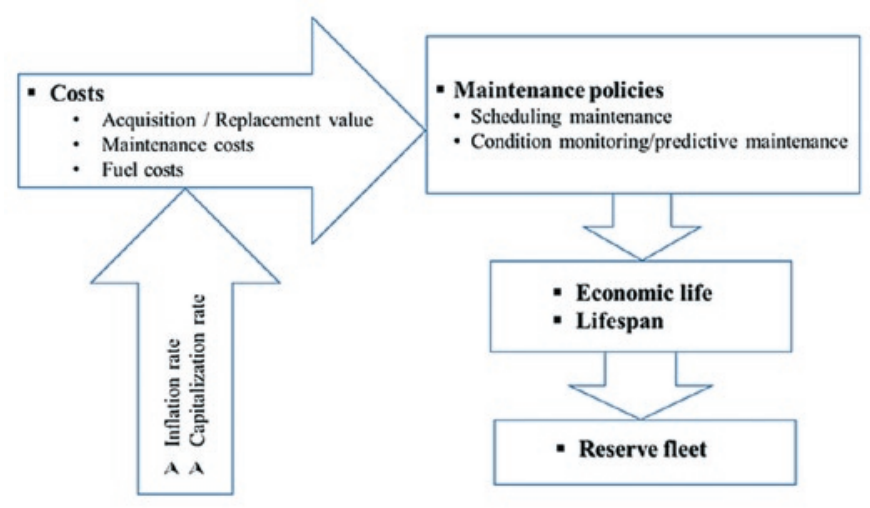

Fig. 3.1 - Integrative Model for Dimensioning a Reserve Fleet

\section{Some theoretical models for asset replacement deci- sion process}

To analyze equipment replacement, two variables should be taken into account:

- Capitalization rate, $i$

- Inflation rate, $\theta$.

These rates are related in the following manner:

$$
i_{A}=i+\theta+i \theta
$$

where

$$
i_{A}=\text { Apparent rate }
$$

Farinha [22] suggest several methods to determine the economic life cycle. One of these, the Annual Uniform Method (AUM), makes use of the following data:

- Cost of acquisition;

- Withdrawal value;

- Maintenance and operating costs over time;

- Apparent rate.

This paper uses the exponential method to calculate the withdrawal value of a bus; when there are no real data from the market, as is the case here, it is necessary to simulate the equipment depreciation. The exponential method seems adequate because of the high devaluation of this type of equipment over time. The formula that permit us to evaluate the annual cost depreciation can be expressed as:

$$
\begin{gathered}
d_{l}=V C_{l-1}\left(1-\sqrt[N]{\frac{V C_{N}}{C A}}\right) \\
V_{n}=V C_{l-1}-d_{l}
\end{gathered}
$$

where

- $d_{l} \quad$ Annual depreciation quota;

- $C A$ Cost of Acquisition;

- $N$ Time of life corresponding to $\mathrm{VC}_{\mathrm{N}}$;

- $V C_{N}$ Residual value of the equipment at the end of $\mathrm{N}$ periods of time;

- $l \quad l=1,2,3 \ldots \mathrm{N}$;

- $V_{n}$ Equipment value in period $\mathrm{n}=1,2,3 \ldots \mathrm{N}$.

The Present Net Value per year $n\left(P N V_{n}\right)$ is expressed as follows: 


$$
P N V_{n}=C A+\sum_{j=0}^{n} \frac{C M_{j}+C O_{j}}{\left(1+i_{A}\right)^{j}}-\frac{V_{n}}{\left(1+i_{A}\right)^{n}}
$$

where

- $C M_{j}$ Cost of maintenance per year $\mathrm{j}=1,2,3 \ldots \mathrm{n}$;

- $C O_{j}$ Cost of operation per year $\mathrm{j}=1,2,3 \ldots \mathrm{n}$.

The Uniform Annual Income $\left(U A I_{n}\right)$ is written as follows:

$$
\begin{gathered}
U A I_{n}=\frac{i_{A}\left(1+i_{A}\right)^{n}}{\left(1+i_{A}\right)^{n-1}}\left(C A+\sum_{j=0}^{n} \frac{C M_{j}+C O_{j}}{\left(1+i_{A}\right)^{j}}-\frac{V_{n}}{\left(1+i_{A}\right)^{n}}\right) \\
U A I_{n}=\frac{i_{A}\left(1+i_{A}\right)^{n}}{\left(1+i_{A}\right)^{n-1}} N P V_{n}
\end{gathered}
$$

The UAI indicates the time (in years) when a bus ought to be replaced. This value is equivalent to the minimum annual cost of the bus.

Another method to determine the economic cycle of equipment replacement is the Minimization of Total Average Cost Method (MTACM). This method permits the determination of the lowest average cost of bus ownership that corresponds to the most rational optimal replacement time. The capital cost and the inflation rate are not considered. The calculation procedure is as follows:

$$
\begin{gathered}
C_{n}^{\prime}=\frac{1}{n} \sum_{j=1}^{n}\left(C M_{j}+C O_{j}\right) \\
C_{n}^{\prime \prime}=\frac{1}{n}\left(C A-V_{n}\right) \\
C_{n(\text { MMTAC })}=C_{n}^{\prime}+C_{n}^{\prime \prime}=\min _{n \in\{1,2, \ldots, N\}} \frac{1}{n}\left(C A-V_{n}+\sum_{j=1}^{n}\left(C M_{j}+C O_{j}\right)\right)(9)
\end{gathered}
$$

where

- $n \quad$ Number of years $n \in\{1,2,3 \ldots N\}$;

- $C_{n}^{\prime} \quad$ Auxiliary variable;

- $C^{\prime \prime}{ }_{n} \quad$ Auxiliary variable;

- $C_{n(M T A C M)}$ Total average cost.

A final option is the MTACM Reduced to Present Value (MMTAC$\mathrm{RPV})$. The calculation procedure is the same as the one above but it also considers the capital cost and inflation rate. The various maintenance and withdrawal values over time are reduced to the present value, using the following procedure:

$$
\begin{gathered}
C_{n}^{\prime}=\frac{1}{n} \sum_{j=1}^{n}\left(\frac{C M_{j}+C O_{j}}{\left(1+i_{A}\right)^{j}}\right) \\
C_{n}^{\prime \prime}=\frac{1}{n}\left(C A-\frac{V_{n}}{\left(1+i_{A}\right)^{n}}\right)
\end{gathered}
$$

$C_{n(M M T A C-R P V)}=C_{n}^{\prime}+C_{n}^{\prime \prime}=\min _{n \in\{1,2, \ldots, N\}} \frac{1}{n}\left(C A-\frac{V_{n}}{\left(1+i_{A}\right)^{n}}+\sum_{j=1}^{n}\left(\frac{C M_{j}+C O_{j}}{\left(1+i_{A}\right)^{j}}\right)\right)$

where
- $\mathrm{C}_{\mathrm{n} \text { (MTACM-RPV) }}$ Total Average Cost Reduced to Present Value.

An increase in business competitiveness always implies a cross dialogue between maintenance activity and economic management; therefore, it is important to consider economic variables like Return on Investment (ROI). ROI is related to greatest asset availability at the lowest cost; it determines the present value of the capital investment and cash flow corrected through the apparent rate expressed as:

$$
R O I=\sum_{j=1}^{n} \frac{C F_{j}}{\left(1+i_{A}\right)^{j}}-C A
$$

where

$$
\text { - } C F_{j} \text { Cash Flow; }
$$$$
\bullet j \quad j=1,2,3 \ldots n \text {. }
$$

The Uniform Annual Income $\left(U A I_{n}\right)$ and ROI can be written conjunctly as:

$$
\left\{\begin{array}{c}
U A I_{n}=\frac{i_{A}\left(1+i_{A}\right)^{n}}{\left(1+i_{A}\right)^{n-1}}\left(C A+\sum_{j=1}^{n} \frac{C M_{j}+C O_{j}}{\left(1+i_{A}\right)^{j}}-\frac{V_{n}}{\left(1+i_{A}\right)^{n}}\right) \\
R O I=\sum_{j=1}^{n} \frac{C F_{j}}{\left(1+i_{A}\right)^{j}}-C A
\end{array}\right.
$$

The Minimization of Total Average Cost Method (MMTAC) and Return on Investment (ROI) can be written conjunctly as:

$$
\left\{\begin{array}{c}
C_{n(\text { MMTAC })}=\min _{n \in\{1,2, \ldots, N\}} \frac{1}{n}\left(C A-V_{n}+\sum_{j=1}^{n}\left(C M_{j}+C O_{j}\right)\right) \\
R O I=\sum_{j=1}^{n} \frac{C F_{j}}{\left(1+i_{A}\right)^{j}}-C A
\end{array}\right.
$$

The MMTAC Reduced to Present Value (MMTAC-RPV) and Return on Investment (ROI) can be written conjunctly as:

$$
\left\{\begin{array}{c}
C_{n(M M T A C-R P V)}=\min _{n \in\{1,2, \ldots, N\}} \frac{1}{n}\left(C A-\frac{V_{n}}{\left(1+i_{A}\right)^{n}}+\sum_{j=1}^{n}\left(\frac{C M_{j}+C O_{j}}{\left(1+i_{A}\right)^{j}}\right)\right)_{(16)} \\
R O I=\sum_{j=1}^{n} \frac{C F_{j}}{\left(1+i_{A}\right)^{j}}-C A
\end{array}\right.
$$

To apply the models, direct operating costs and maintenance costs are taken into consideration, as are the relevant economic indicators, such as inflation and interest rates.

The study described in this paper began with a survey of the operating data for a bus fleet belonging to a medium-sized urban transport company. Based on these data, a pilot project to validate the replacement model created a simulation using a reduced number of buses. The project used historical data from 1993 to 2014. The buses were put into homogeneous groups: the buses were $21,18,16,12$, and 11 years old.

\section{Oil analysis as a covariate for RUL prediction}

There are several techniques for asset condition monitoring, like the followings: vibration analysis, thermography, visual inspection, ultrasonic measurement, and oil analysis. Among these techniques, oil analysis plays an important key role in the condition monitoring of combustion engines including the estimating of its Remaining Useful Life (RUL). 


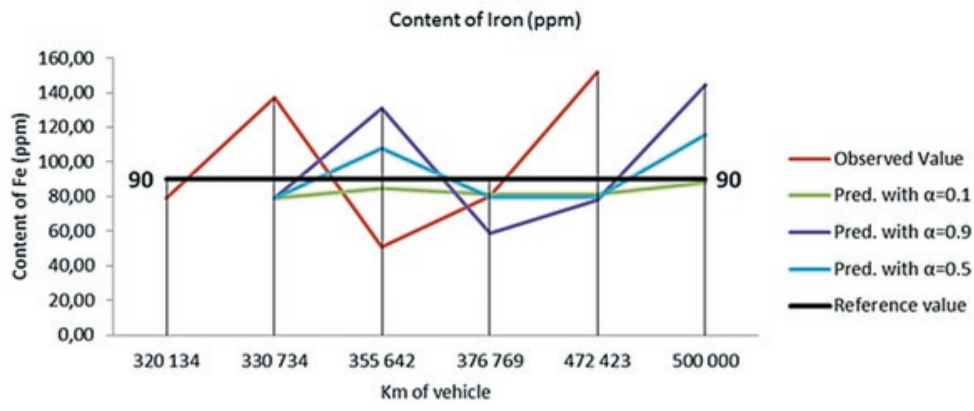

Fig. 5.3 - Predicted Values for Iron Content (Bus X1)

In Figure 5.3, the iron content increases, then suddenly decreases, dropping under the reference value. This happens when the oil is changed. The situation repeats in each utilization cycle.

Oil analysis is most effective when it is used to track metrics or benchmarks set in the planning stage. The goal is to improve the lifespan and increase MTBF by creating a performance metric that can be used to measure compliance with the stated reliability goals. Metrics provide accountability, not just for those directly involved with the oil analysis program, but for the whole plant, sending a clear message that lubrication and oil analysis are an important part of the fleet's strategy to achieve both maintenance and performance objectives. The final stage of oil analysis is to evaluate the effectiveness of the program. This should include a cost benefit evaluation of maintenance "saves" because of oil analysis. Ongoing evaluation permits continuous improvement of the program by realigning it with either preexisting or new reliability objectives.

\section{Condition based maintenance versus reserve fleet}

The development and implementation of a policy to support strategies based on condition monitoring as described in the previous section, especially predictive maintenance, imply the consolidation of several monitoring systems. Monitoring bus "health" through condition variables will dramatically improve the optimization of the maintenance intervals, usually increasing them (the original planned preventive maintenance intervals are usually conservative), with the following implications:

- Eliminating unnecessary disassembly of parts of equipment for inspection, thereby increasing the availability of the vehicle and decreasing the maintenance costs;

- Reducing unplanned maintenance, thus increasing the availability of the vehicle and decreasing the maintenance costs;

- Reducing severe service shutdowns, increasing bus reliability and decreasing bus unavailability and immobilization costs;

- Detecting problems before they become critical, reducing intervention costs;

- Increasing the useful life of the components and the bus, thus increasing profitability.

Monitoring the condition maintenance variables may influence the reliability indicators, i.e., the MTTR and the Availability (A). The following well-known equations express the Availability, the MTTR and MTBF as a function of A:

$$
A=\frac{M T B F}{M T B F+M T T R}
$$

$$
\begin{gathered}
M T T R=M T B F \frac{(1-A)}{A} \\
M T B F=\frac{M T T R}{\frac{(1-A)}{A}}
\end{gathered}
$$

Although these equations are simple, they express the relevance of the MTBF and MTTR on operational availability. In this type of vehicle (bus fleets), increasing availability by diminishing MTTR should have the direct consequence of diminishing the reserve fleet and, by consequence, the respective costs.

Figures 6.1, 6.2 and 6.3 show that when the MTTR decreases, the bus availability increases. When the MTBF increases, the bus availability also increases. Although this conclusion seems obvious, especially when the covariate oil quality is highly correlated with asset degradation, it has strategic consequences for the reserve fleet - each extra bus in the fleet represents many thousands of euros.

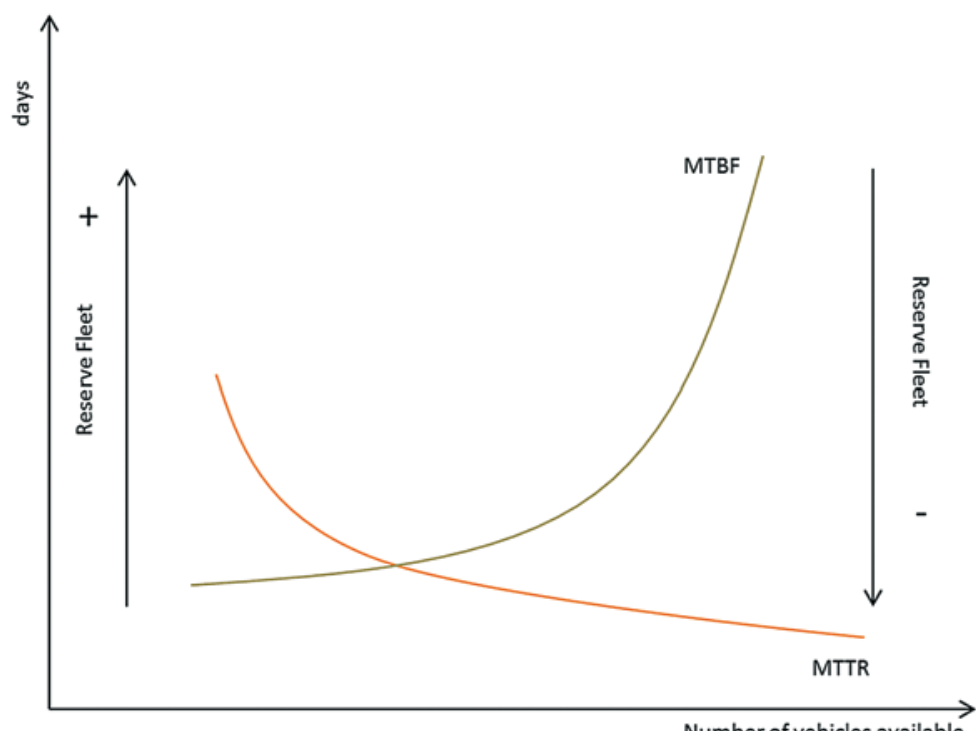

Fig. 6.1 - MTTR and MTBF versus Reserve Fleet

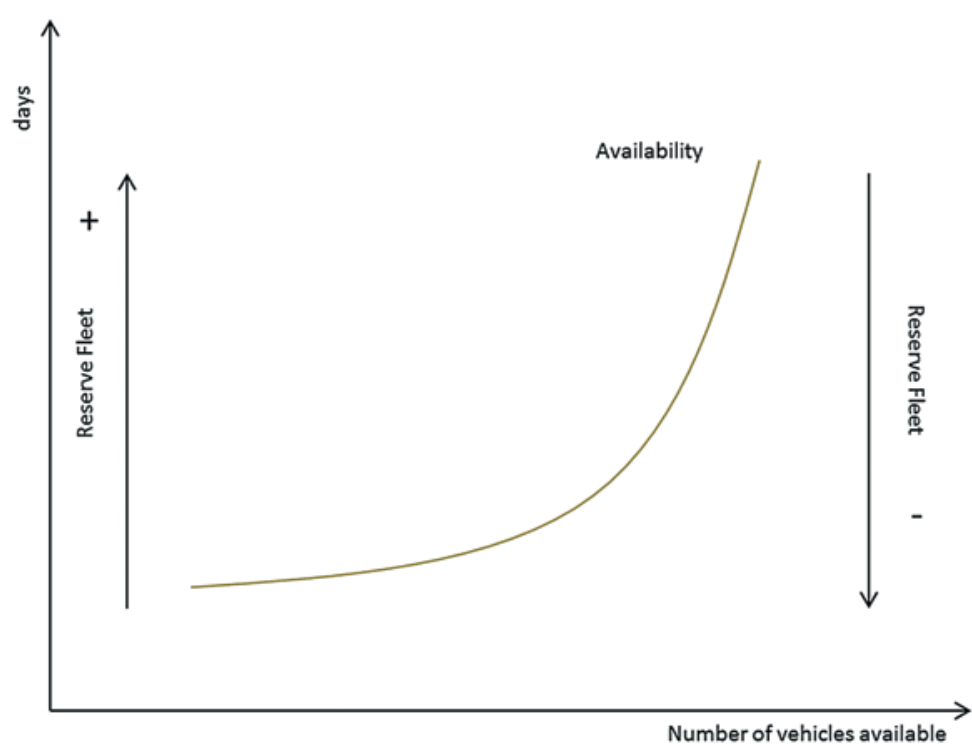

Fig. 6.2 - Availability versus Reserve Fleet 
The variations in the size of the reserve fleet based on several values simulated for the MTTR are shown in Table 6.1. This table and Figure 6.3 clearly demonstrate that a policy of condition monitoring leads to a higher MTBF, a lower MTTR and, consequently, increased Availability.

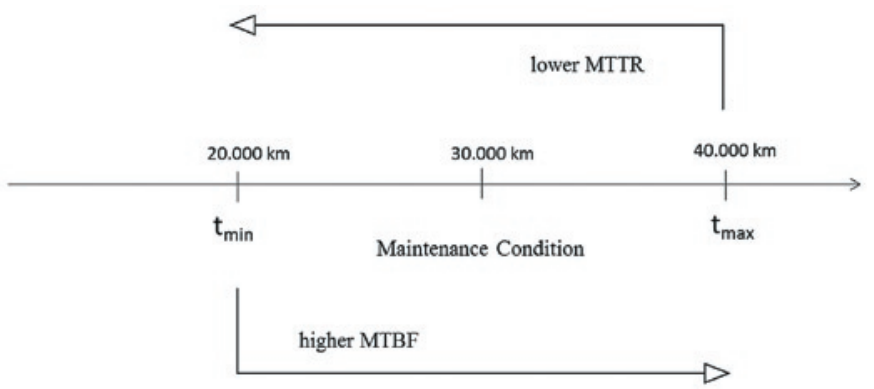

Fig. 6.3 - Maintenance Condition versus TTR/TBF (MTTR/MTBF)

Table 6.1 - MTTR versus Reserve Fleet

$\begin{array}{cccc}\text { MTTR [days] } & \text { Bus Fleet }[\mathrm{m}] & \begin{array}{c}\text { Reserve Fleet } \\ {[\mathrm{RF}]}\end{array} & \text { Interval [RF] } \\ 5 & 100 & 1,4 & {[1,2]} \\ 10 & 100 & 2,7 & {[2,3]} \\ 15 & 100 & 4,1 & {[4,5]} \\ 20 & 100 & 5,5 & {[5,6]} \\ 25 & 100 & 6,8 & {[6,7]} \\ 30 & 100 & 8,2 & {[8,9]}\end{array}$

It is also important to demonstrate the effect of the relations of these indicators on the size of the reserve fleet. From Table 6.1, formula (22) can be inferred to determine the size of the reserve fleet:

$$
R F=\frac{m M T T R}{k}
$$

where

- $R F \quad$ Reserve fleet;

- $m \quad$ Number of fleet buses;

- MTTR Mean Time to Repair (days);

- $k \quad$ Number of days (in our case 365).

According to Table 6.1, the size of the reserve fleet increases with the MTTR. The lower this indicator, the lower the company's investment in a reserve fleet. The emphasis is placed on the MTTR because of its high impact on management costs, especially the indirect ones. Even a small increase in the MTTR value corresponds to an increase in the reserve fleet cost, because of the high cost of each bus, as mentioned previously.

It can be concluded that the reliability KPI's under discussion and the maintenance policies practiced by road transport companies have an enormous impact on maintenance costs and on the size of the reserve fleet. This subject is discussed in more detail in the next section.

\section{Influence of MTTR on replacement time and ROI}

This section discusses the influence of the MTTR on the economic cycle of bus replacement, along the bus life cycle. It also integrates the Return on Investment (ROI) of a bus with the economic cycle of bus replacement.

The Uniform Annual Income $\left(\mathrm{UAI}_{\mathrm{n}}\right)$ Method as a function of the Mean Time to Repair (MTTR), taking into account the Return On Investment (ROI), can be written as:

$$
\left\{\begin{array}{c}
U A I_{n}=\frac{i_{A}\left(1+i_{A}\right)^{n}}{\left(1+i_{A}\right)^{n-1}}\left(C A+\sum_{j=1}^{n} \frac{\left(t M T T R \frac{C M_{j}}{d}\right)+C O_{j}}{\left(1+i_{A}\right)^{j}}-\frac{V_{n}}{\left(1+i_{A}\right)^{n}}\right. \\
R O I=\sum_{j=1}^{n} \frac{C F_{j}}{\left(1+i_{A}\right)^{j}}-C A
\end{array}\right.
$$

where

\section{- $t \quad$ Number of intervals considered for MTTR;}

- $d$ Number of days per year.

The Minimization Method of Total Average Cost (MMTAC) as a function of MTTR and ROI can be written as follows:

$$
\left\{\begin{array}{c}
C_{n(M M T A C)}=\min _{n \in\{1,2, \ldots, N\}} \frac{1}{n}\left(C A-V_{n}+\sum_{j=1}^{n}\left(\left(t M T T R \frac{C M_{j}}{d}\right)+C O_{j}\right)\right) \\
R O I=\sum_{j=1}^{n} \frac{C F_{j}}{\left(1+i_{A}\right)^{j}}-C A
\end{array}\right.
$$

The MMTAC Reduced to Present Value (MMTAC-RPV) in function of MTTR and ROI can be written as:

$$
\left\{\begin{array}{c}
C_{n(M M T A C-R P V)}=\min _{n \in\{1,2, \ldots, N\}} \frac{1}{n}\left(C A-\frac{V_{n}}{\left(1+i_{A}\right)^{n}}+\sum_{j=1}^{n}\left(\frac{\left(t M T T R \frac{C M_{j}}{d}\right)+C O_{j}}{\left(1+i_{A}\right)^{j}}\right)\right) \\
R O I=\sum_{j=1}^{n} \frac{C F_{j}}{\left(1+i_{A}\right)^{j}}-C A
\end{array}\right.
$$

The paper has emphasized the importance of condition monitoring, its relations with the MTTR and the importance of this KPI to the time of bus replacement. An example of the influence of this ratio, using the Uniform Annual Income method, is given in Table 7.1 and Figure 7.1. The table and the figure clearly show the effect of the

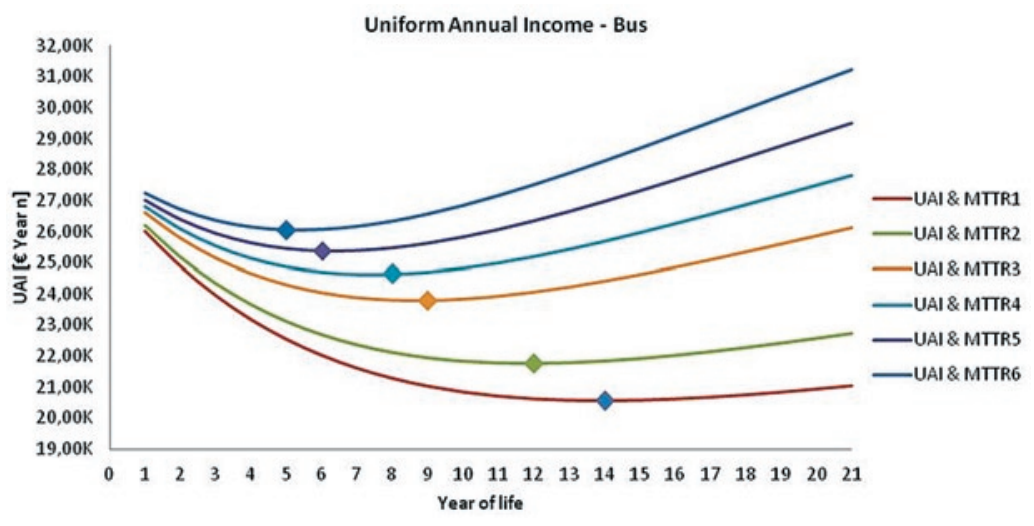

Figure 7.1 - Influence of MTTR on UAI - ROI 
Table 7.1 - Influence of MTTR on UAI

\begin{tabular}{|c|c|c|c|c|c|c|c|c|c|c|c|c|c|c|c|}
\hline \multicolumn{10}{|c|}{ Vehicles } & \multicolumn{6}{|c|}{ UAI $[€$ Year $n]$} \\
\hline Year & Year $\mathrm{J}$ & CA $[€]$ & $\mathrm{i}_{\mathrm{A}}[\%]$ & MTTR $_{1}$ & $\mathrm{MTTR}_{2}$ & $\mathrm{MTTR}_{\mathrm{y}}$ & MTTR $_{4}$ & MTTR & MTTR $_{8}$ & UAI \& MTTR & UAI \& MTTR & UAI \& MTTR & UAI \& MTTR & UAI \& MTTR & UAI \& MTTR \\
\hline 1993 & 0 & \begin{tabular}{|l|}
$110.66 \mathrm{~K}$ \\
\end{tabular} & $8 \%$ & & & & & & & & & & & & \\
\hline 1994 & 1 & & $8 \%$ & 5 & 10 & 20 & 25 & 30 & 35 & $25.99 \mathrm{~K}$ & $26.20 \mathrm{~K}$ & $26.61 \mathrm{~K}$ & $26.81 \mathrm{~K}$ & $27.02 \mathrm{~K}$ & $27.22 \mathrm{~K}$ \\
\hline 1995 & 2 & & $8 \%$ & 5 & 10 & 20 & 25 & 30 & 35 & $24.88 \mathrm{~K}$ & $25.18 \mathrm{~K}$ & $25.79 \mathrm{~K}$ & $26.09 \mathrm{~K}$ & $26.40 \mathrm{~K}$ & $26.70 \mathrm{~K}$ \\
\hline 1996 & 3 & & $8 \%$ & 5 & 10 & 20 & 25 & 30 & 35 & $23.94 \mathrm{~K}$ & $24.34 \mathrm{~K}$ & $25.14 \mathrm{~K}$ & $25.54 \mathrm{~K}$ & $25.95 \mathrm{~K}$ & $26.35 \mathrm{~K}$ \\
\hline 1997 & 4 & & $8 \%$ & 5 & 10 & 20 & 25 & 30 & 35 & $23.17 \mathrm{~K}$ & $23.67 \mathrm{~K}$ & $24.65 \mathrm{~K}$ & $25.15 \mathrm{~K}$ & $25.64 \mathrm{~K}$ & $26.13 \mathrm{~K}$ \\
\hline 1998 & 5 & & $8 \%$ & 5 & 10 & 20 & 25 & 30 & 35 & $22.54 \mathrm{~K}$ & $23.12 \mathrm{~K}$ & $24.29 \mathrm{~K}$ & $24.87 \mathrm{~K}$ & $25.46 \mathrm{~K}$ & $26.04 \mathrm{~K}$ \\
\hline 1999 & 6 & & $8 \%$ & 5 & 10 & 20 & 25 & 30 & 35 & $22.02 \mathrm{~K}$ & $22.69 \mathrm{~K}$ & $24.04 \mathrm{~K}$ & $21.71 \mathrm{~K}$ & $25.38 \mathrm{~K}$ & $26.05 \mathrm{~K}$ \\
\hline 2000 & 7 & & $8 \%$ & 5 & 10 & 20 & 25 & 30 & 35 & $21.61 \mathrm{~K}$ & $22.36 \mathrm{~K}$ & $23.88 \mathrm{~K}$ & $24.64 \mathrm{~K}$ & $25.39 \mathrm{~K}$ & $26.15 \mathrm{~K}$ \\
\hline 2001 & 8 & & $8 \%$ & 5 & 10 & 20 & 25 & 30 & 35 & $21.28 \mathrm{~K}$ & $22.12 \mathrm{~K}$ & $23.80 \mathrm{~K}$ & $24.64 \mathrm{~K}$ & $25.48 \mathrm{~K}$ & $26.32 \mathrm{~K}$ \\
\hline 2002 & 9 & & $8 \%$ & 5 & 10 & 20 & 25 & 30 & 35 & $21.03 \mathrm{~K}$ & $21.95 \mathrm{~K}$ & $23.79 \mathrm{~K}$ & $24.71 \mathrm{~K}$ & $25.63 \mathrm{~K}$ & $26.55 \mathrm{~K}$ \\
\hline 2003 & 10 & & $8 \%$ & 5 & 10 & 20 & 25 & 30 & 35 & $20.84 \mathrm{~K}$ & $21.84 \mathrm{~K}$ & $23.83 \mathrm{~K}$ & $24.83 \mathrm{~K}$ & $25.83 \mathrm{~K}$ & $26.83 \mathrm{~K}$ \\
\hline 2004 & 11 & & $8 \%$ & 5 & 10 & 20 & 25 & 30 & 35 & $20.70 \mathrm{~K}$ & $21.78 \mathrm{~K}$ & $23,92 \mathrm{~K}$ & $25.00 \mathrm{~K}$ & $26.07 \mathrm{~K}$ & $27.15 \mathrm{~K}$ \\
\hline 2005 & 12 & & $8 \%$ & 5 & 10 & 20 & 25 & 30 & 35 & $20.62 \mathrm{~K}$ & $21.76 \mathrm{~K}$ & $24.06 \mathrm{~K}$ & $25.20 \mathrm{~K}$ & $26.35 \mathrm{~K}$ & $27.49 \mathrm{~K}$ \\
\hline 2006 & 13 & & $8 \%$ & 5 & 10 & 20 & 25 & 30 & 35 & $20.57 \mathrm{~K}$ & $21.79 \mathrm{~K}$ & $24.22 \mathrm{~K}$ & $25.44 \mathrm{~K}$ & $26.65 \mathrm{~K}$ & $27.87 \mathrm{~K}$ \\
\hline 2007 & 14 & & $8 \%$ & 5 & 10 & 20 & 25 & 30 & 35 & $20.56 \mathrm{~K}$ & $21.84 \mathrm{~K}$ & $24.41 \mathrm{~K}$ & $25.69 \mathrm{~K}$ & $26.98 \mathrm{~K}$ & $28.26 \mathrm{~K}$ \\
\hline 2008 & 15 & & $8 \%$ & 5 & 10 & 20 & 25 & 30 & 35 & $20.57 \mathrm{~K}$ & $21.92 \mathrm{~K}$ & $24.62 \mathrm{~K}$ & $25.97 \mathrm{~K}$ & $27.32 \mathrm{~K}$ & $28.67 \mathrm{~K}$ \\
\hline 2009 & 16 & & $8 \%$ & 5 & 10 & 20 & 25 & 30 & 35 & $20.61 \mathrm{~K}$ & $22.02 \mathrm{~K}$ & $24.85 K$ & $26.26 \mathrm{~K}$ & $27.67 \mathrm{~K}$ & $29.09 \mathrm{~K}$ \\
\hline 2010 & 17 & & $8 \%$ & 5 & 10 & 20 & 25 & 30 & 35 & $20.67 \mathrm{~K}$ & $22.14 \mathrm{~K}$ & $25.09 \mathrm{~K}$ & $26.56 \mathrm{~K}$ & $28.04 \mathrm{~K}$ & $29.51 \mathrm{~K}$ \\
\hline 2011 & 18 & & $8 \%$ & 5 & 10 & 20 & 25 & 30 & 35 & $20.74 \mathrm{~K}$ & $22.28 \mathrm{~K}$ & $25.34 \mathrm{~K}$ & $26.87 \mathrm{~K}$ & $28.40 \mathrm{~K}$ & $29.94 K$ \\
\hline 2012 & 19 & & $8 \%$ & 5 & 10 & 20 & 25 & 30 & 35 & $20.83 \mathrm{~K}$ & $22.42 \mathrm{~K}$ & $25.60 \mathrm{~K}$ & $27.18 \mathrm{~K}$ & $28.77 \mathrm{~K}$ & $30.36 \mathrm{~K}$ \\
\hline 2013 & 20 & & $8 \%$ & 5 & 10 & 20 & 25 & 30 & 35 & $20.93 \mathrm{~K}$ & $22.57 \mathrm{~K}$ & $25.86 \mathrm{~K}$ & $27.50 \mathrm{~K}$ & $29.14 \mathrm{~K}$ & $30.79 \mathrm{~K}$ \\
\hline 2014 & 21 & & $8 \%$ & 5 & 10 & 20 & 25 & 30 & 35 & $21.04 \mathrm{~K}$ & $22.73 \mathrm{~K}$ & $26.12 \mathrm{~K}$ & $27.82 \mathrm{~K}$ & $29.51 \mathrm{~K}$ & $31.21 \mathrm{~K}$ \\
\hline
\end{tabular}

Table 7.2 - MTTR versus UAI - ROI

\begin{tabular}{|c|c|c|c|c|c|c|c|c|c|c|c|c|c|c|c|c|}
\hline \multicolumn{10}{|c|}{ Vehicles } & \multicolumn{6}{|c|}{ UAI [ $€$ Year $n]$} & \multirow{2}{*}{$\mathrm{ROI}$} \\
\hline Year & Year J & CA [€] & $I_{A}[\%]$ & $M T T R_{1}$ & M TTR & M TTR, & $M T T R_{4}$ & $M T T R_{g}$ & M TTR & UAI \& M TTR & UAI \& $M T T R_{2}$ & UAI \& MTTR, & UAI \& MTTR & UAI \& M TTR, & UAI \& M TTR & \\
\hline 1993 & $\overline{0}$ & $110.66 \mathrm{~K}$ & $8 \%$ & & & & & & & & & & & & & \\
\hline 1994 & 1 & & $8 \%$ & 5 & 10 & 20 & 25 & 30 & 35 & $25.99 \mathrm{~K}$ & $26.20 \mathrm{~K}$ & $26.61 \mathrm{~K}$ & $26.81 \mathrm{~K}$ & $27.02 \mathrm{~K}$ & $27.22 \mathrm{~K}$ & $-87.51 \mathrm{~K}$ \\
\hline 1995 & 2 & & $8 \%$ & 5 & 10 & 20 & 25 & 30 & 35 & $24.88 \mathrm{~K}$ & $25.18 \mathrm{~K}$ & $25.79 \mathrm{~K}$ & $26.09 \mathrm{~K}$ & $26.40 \mathrm{~K}$ & $26.70 \mathrm{~K}$ & $-70.36 \mathrm{~K}$ \\
\hline 1996 & 3 & & $8 \%$ & 5 & 10 & 20 & 25 & 30 & 35 & $23.94 \mathrm{~K}$ & $24.34 \mathrm{~K}$ & $25.14 \mathrm{~K}$ & $25.54 \mathrm{~K}$ & $25.95 \mathrm{~K}$ & $26.35 \mathrm{~K}$ & $-54.57 \mathrm{~K}$ \\
\hline 1997 & 4 & & $8 \%$ & 5 & 10 & 20 & 25 & 30 & 35 & $23.17 \mathrm{~K}$ & $23.67 \mathrm{~K}$ & $24.65 \mathrm{~K}$ & $25.15 \mathrm{~K}$ & $25.64 \mathrm{~K}$ & $26.13 \mathrm{~K}$ & $-40.01 \mathrm{~K}$ \\
\hline 1998 & 5 & & $8 \%$ & 5 & 10 & 20 & 25 & 30 & 35 & $22.54 \mathrm{~K}$ & $23.12 \mathrm{~K}$ & $24.29 \mathrm{~K}$ & $24.87 \mathrm{~K}$ & $25.46 \mathrm{~K}$ & $26.04 \mathrm{~K}$ & $-26.61 \mathrm{~K}$ \\
\hline 1999 & 6 & & $8 \%$ & 5 & 10 & 20 & 25 & 30 & 35 & $22.02 \mathrm{~K}$ & $22.69 \mathrm{~K}$ & $24.04 \mathrm{~K}$ & $21.71 \mathrm{~K}$ & $25.38 \mathrm{~K}$ & $26.05 \mathrm{~K}$ & $-14.25 \mathrm{~K}$ \\
\hline 2000 & 7 & & $8 \%$ & 5 & 10 & 20 & 25 & 30 & 35 & $21.61 \mathrm{~K}$ & $22.36 \mathrm{~K}$ & $23.88 \mathrm{~K}$ & $24.64 \mathrm{~K}$ & $25.39 \mathrm{~K}$ & $26.15 \mathrm{~K}$ & $-2.88 \mathrm{~K}$ \\
\hline 2001 & 8 & & $8 \%$ & 5 & 10 & 20 & 25 & 30 & 35 & $21.28 \mathrm{~K}$ & $22.12 \mathrm{~K}$ & $23.80 \mathrm{~K}$ & $24.64 \mathrm{~K}$ & $25.48 \mathrm{~K}$ & $26.32 \mathrm{~K}$ & $7.61 \mathrm{~K}$ \\
\hline 2002 & 9 & & $8 \%$ & 5 & 10 & 20 & 25 & 30 & 35 & $21.03 \mathrm{~K}$ & $21.95 \mathrm{~K}$ & $23.79 \mathrm{~K}$ & $24.71 \mathrm{~K}$ & $25.63 \mathrm{~K}$ & $26.55 \mathrm{~K}$ & $17.26 \mathrm{~K}$ \\
\hline 2003 & 10 & & $8 \%$ & 5 & 10 & 20 & 25 & 30 & 35 & $20.84 \mathrm{~K}$ & $21.84 \mathrm{~K}$ & $23.83 \mathrm{~K}$ & $24.83 \mathrm{~K}$ & $25.83 \mathrm{~K}$ & $26.83 \mathrm{~K}$ & $26.15 \mathrm{~K}$ \\
\hline 2004 & 11 & & $8 \%$ & 5 & 10 & 20 & 25 & 30 & 35 & $20.70 \mathrm{~K}$ & $21.78 \mathrm{~K}$ & $23,92 \mathrm{~K}$ & $25.00 \mathrm{~K}$ & $26.07 \mathrm{~K}$ & $27.15 \mathrm{~K}$ & $34.35 \mathrm{~K}$ \\
\hline 2005 & 12 & & $8 \%$ & 5 & 10 & 20 & 25 & 30 & 35 & $20.62 \mathrm{~K}$ & $21.76 \mathrm{~K}$ & $24.06 \mathrm{~K}$ & $25.20 \mathrm{~K}$ & $26.35 \mathrm{~K}$ & $27.49 \mathrm{~K}$ & $41.89 \mathrm{~K}$ \\
\hline 2006 & 13 & & $8 \%$ & 5 & 10 & 20 & 25 & 30 & 35 & $20.57 \mathrm{~K}$ & $21.79 \mathrm{~K}$ & $24.22 \mathrm{~K}$ & $25.44 \mathrm{~K}$ & $26.65 \mathrm{~K}$ & $27.87 \mathrm{~K}$ & $48.84 \mathrm{~K}$ \\
\hline 2007 & 14 & & $8 \%$ & 5 & 10 & 20 & 25 & 30 & 35 & $20.56 \mathrm{~K}$ & $21.84 \mathrm{~K}$ & $24.41 \mathrm{~K}$ & $25.69 \mathrm{~K}$ & $26.98 \mathrm{~K}$ & $28.26 \mathrm{~K}$ & $55.24 \mathrm{~K}$ \\
\hline 2008 & 15 & & $8 \%$ & 5 & 10 & 20 & 25 & 30 & 35 & $20.57 \mathrm{~K}$ & $21.92 \mathrm{~K}$ & $24.62 \mathrm{~K}$ & $25.97 \mathrm{~K}$ & $27.32 \mathrm{~K}$ & $28.67 \mathrm{~K}$ & $61.14 \mathrm{~K}$ \\
\hline 2009 & 16 & & $8 \%$ & 5 & 10 & 20 & 25 & 30 & 35 & $20.61 \mathrm{~K}$ & $22.02 \mathrm{~K}$ & $24.85 \mathrm{~K}$ & $26.26 \mathrm{~K}$ & $27.67 \mathrm{~K}$ & $29.09 \mathrm{~K}$ & $66.56 \mathrm{~K}$ \\
\hline 2010 & 17 & & $8 \%$ & 5 & 10 & 20 & 25 & 30 & 35 & $20.67 \mathrm{~K}$ & $22.14 \mathrm{~K}$ & $25.09 \mathrm{~K}$ & $26.56 \mathrm{~K}$ & $28.04 \mathrm{~K}$ & $29.51 \mathrm{~K}$ & $71.56 \mathrm{~K}$ \\
\hline 2011 & 18 & & $8 \%$ & 5 & 10 & 20 & 25 & 30 & 35 & $20.74 \mathrm{~K}$ & $22.28 \mathrm{~K}$ & $25.34 \mathrm{~K}$ & $26.87 \mathrm{~K}$ & $28.40 \mathrm{~K}$ & $29.94 \mathrm{~K}$ & $76.17 \mathrm{~K}$ \\
\hline 2012 & 19 & & $8 \%$ & 5 & 10 & 20 & 25 & 30 & 35 & $20.83 \mathrm{~K}$ & $22.42 \mathrm{~K}$ & $25.60 \mathrm{~K}$ & $27.18 \mathrm{~K}$ & $28.77 \mathrm{~K}$ & $30.36 \mathrm{~K}$ & $80.41 \mathrm{~K}$ \\
\hline 2013 & 20 & & $8 \%$ & 5 & 10 & 20 & 25 & 30 & 35 & $20.93 \mathrm{~K}$ & $22.57 \mathrm{~K}$ & $25.86 \mathrm{~K}$ & $27.50 \mathrm{~K}$ & $29.14 \mathrm{~K}$ & $30.79 \mathrm{~K}$ & $84.31 \mathrm{~K}$ \\
\hline 2014 & 21 & & $8 \%$ & 5 & 10 & 20 & 25 & 30 & 35 & $21.04 \mathrm{~K}$ & $22.73 \mathrm{~K}$ & $26.12 \mathrm{~K}$ & $27.82 \mathrm{~K}$ & $29.51 \mathrm{~K}$ & $31.21 \mathrm{~K}$ & $87.91 \mathrm{~K}$ \\
\hline
\end{tabular}

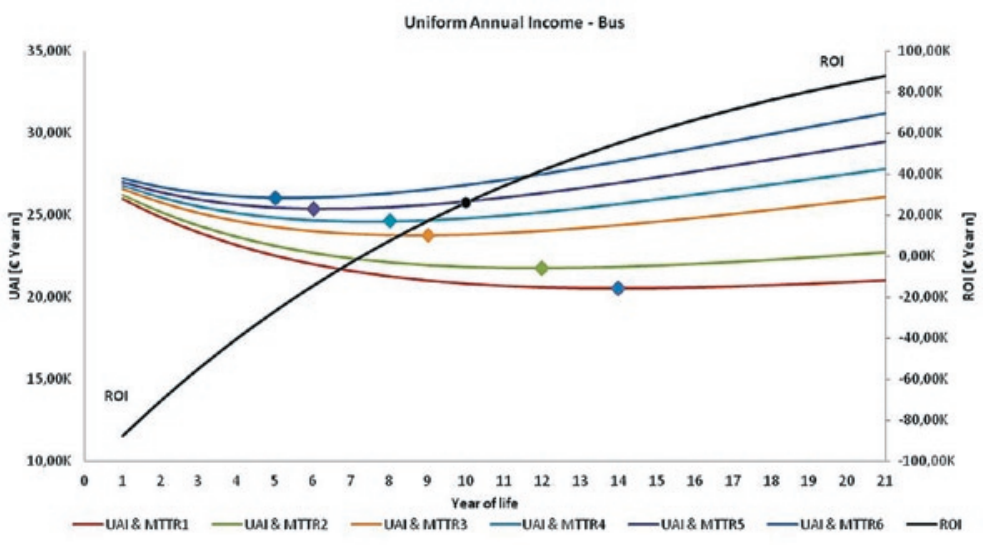

Figure 7.2 - Influence of MTTR on UAI - ROI

MTTR on the bus replacement time. Note: the MTTR values of 5, 10, $20,25,30$ and 35 days were used for the simulation.

Table 7.1 and Figure 7.1 verify the influence of the MTTR in the econometric models. An increase or decrease in the MTTR over time causes a variation on the withdrawal point. The replacement point can vary by more than nine years: i.e. the time for replacement is five years, but if the MTTR decreases, the replacement time becomes 14 years. This shows the importance of this KPI in the management of a bus fleet; it affects the size of the reserve fleet and also the cost.

In addition, it is useful to analyse the relevance of economic ratios to the evaluation of investments, such as the ROI. Table 7.2 and Figure 7.2 show the influence of the MTTR on the calculation of Uniform Annual Income $\left(U A I_{n}\right)$ and on the ROI of a bus. If the UAI curves are compared with the ROI, it becomes obvious that the smaller the UAI, the greater the company's profit.

Table 7.3 and Figure 7.3 focus on a MTTR of five days. It can be noted that for MTTR $=5$ days, the replacement time is 14 years, and the value of the UAI is $20.56 \mathrm{~K} €$. Note that in the $10^{\text {th }}$ year, the ROI value is $26.15 \mathrm{~K} €$. Therefore, the ROI is higher than the value of $U A I_{n}$, and the equipment has started yielding profit to the company. The period between the year the equipment starts giving a profit (year=10) and the year it is replaced corresponds to the year when the UAI is minimal (year=14), with a profit value of $103.19 \mathrm{~K} €$. 
Table 7.3 - Influence of MTTR=5 on UAI with ROI

\begin{tabular}{c|c|c|c|c|c|c}
\hline \multicolumn{5}{|c|}{ Vehicles } & UAI [€ Year $\mathrm{n}]$ & \multirow{2}{*}{ ROI } \\
\hline \hline Year & Year j & CA [€] & $\mathrm{i}_{\mathrm{A}}[\%]$ & MTTR $_{\mathbf{1}}$ & UAI \& MTTR & \\
\hline \hline 1993 & 0 & $110.66 \mathrm{~K}$ & $8 \%$ & & & \\
1994 & 1 & & $8 \%$ & 5 & $25.99 \mathrm{~K}$ & $-87.51 \mathrm{~K}$ \\
1995 & 2 & & $8 \%$ & 5 & $24.88 \mathrm{~K}$ & $-70.36 \mathrm{~K}$ \\
1996 & 3 & & $8 \%$ & 5 & $23.94 \mathrm{~K}$ & $-54.57 \mathrm{~K}$ \\
1997 & 4 & & $8 \%$ & 5 & $23.17 \mathrm{~K}$ & $-40.01 \mathrm{~K}$ \\
1998 & 5 & & $8 \%$ & 5 & $22.54 \mathrm{~K}$ & $-26.61 \mathrm{~K}$ \\
1999 & 6 & & $8 \%$ & 5 & $22.02 \mathrm{~K}$ & $-14.25 \mathrm{~K}$ \\
2000 & 7 & & $8 \%$ & 5 & $21.61 \mathrm{~K}$ & $-2.88 \mathrm{~K}$ \\
2001 & 8 & & $8 \%$ & 5 & $21.28 \mathrm{~K}$ & $7.61 \mathrm{~K}$ \\
2002 & 9 & & $8 \%$ & 5 & $21.03 \mathrm{~K}$ & $17.26 \mathrm{~K}$ \\
2003 & 10 & & $8 \%$ & 5 & $20.84 \mathrm{~K}$ & $26.15 \mathrm{~K}$ \\
2004 & 11 & & $8 \%$ & 5 & $20.70 \mathrm{~K}$ & $34.35 \mathrm{~K}$ \\
2005 & 12 & & $8 \%$ & 5 & $20.62 \mathrm{~K}$ & $41.89 \mathrm{~K}$ \\
2006 & 13 & & $8 \%$ & 5 & $20.57 \mathrm{~K}$ & $48.84 \mathrm{~K}$ \\
2007 & 14 & & $8 \%$ & 5 & $20.56 \mathrm{~K}$ & $55.24 \mathrm{~K}$ \\
2008 & 15 & & $8 \%$ & 5 & $20.57 \mathrm{~K}$ & $61.14 \mathrm{~K}$ \\
2009 & 16 & & $8 \%$ & 5 & $20.61 \mathrm{~K}$ & $66.56 \mathrm{~K}$ \\
2010 & 17 & & $8 \%$ & 5 & $20.67 \mathrm{~K}$ & $71.56 \mathrm{~K}$ \\
2011 & 18 & & $8 \%$ & 5 & $20.74 \mathrm{~K}$ & $76.17 \mathrm{~K}$ \\
2012 & 19 & & $8 \%$ & 5 & $20.83 \mathrm{~K}$ & $80.41 \mathrm{~K}$ \\
2013 & 20 & & $8 \%$ & 5 & $20.93 \mathrm{~K}$ & $84.31 \mathrm{~K}$ \\
2014 & 21 & & $8 \%$ & 5 & $21.04 \mathrm{~K}$ & $87.91 \mathrm{~K}$ \\
\hline
\end{tabular}

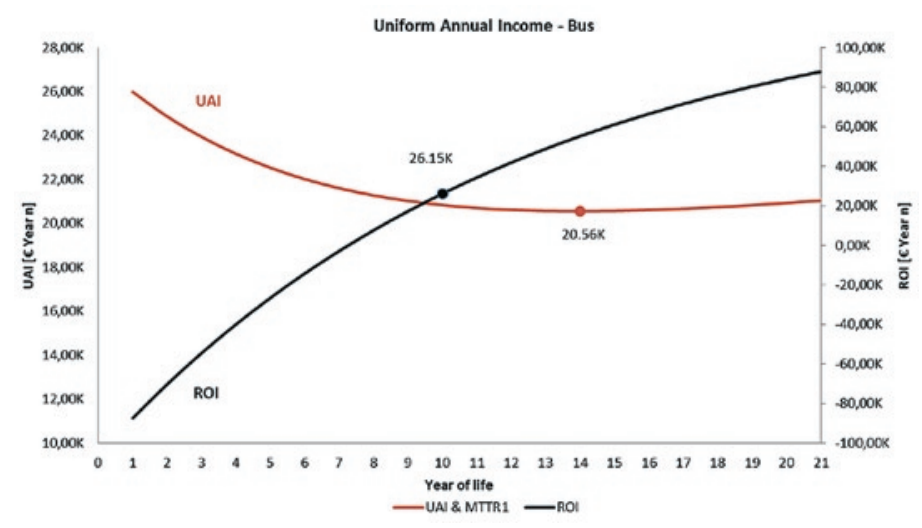

Figure 7.3 - Influence of $M T T R=5$ on UAI with ROI

The example shown in Table 7.4 and Figure 7.4 uses data from the previous example, but with a higher value of ROI per year. The higher ROI is used to show its relevance to company profit when other parameter values remain the same.

The ROI value is higher each year, and the bus starts to give a profit in four years with an ROI value of $55.41 \mathrm{~K} €$. Then, for the period from the time the equipment starts to give profit (year $=4$ ) to the time it is replaced - when the Uniform Annual Income is minimal (=14 years) - the total profit generated by the bus is $1905.76 \mathrm{~K} €$.

\section{Conclusions}

The paper gives an overview of ongoing research in the use of econometric models to determine the optimal time to replace a bus. Indicators associated with acquisition, maintenance and operation costs, among others, guide the economic aspects. The paper demonstrates that the variations in the most rational time to replace a bus are influenced by the MTTR and the ROI.
Table 7.4 - Influence of MTTR=5 on UAI with ROI

\begin{tabular}{|c|c|c|c|c|c|c|}
\hline \multicolumn{5}{|c|}{ Vehicles } & \multirow{2}{*}{$\begin{array}{l}\text { UAI [€ Year n] } \\
\text { UAI \& MTTR }\end{array}$} & \multirow{2}{*}{ ROI } \\
\hline Year & Year j & CA [€] & $\mathrm{i}_{\mathrm{A}}[\%]$ & MTTR $_{1}$ & & \\
\hline 1993 & 0 & $110.66 \mathrm{~K}$ & $8 \%$ & & & \\
\hline 1994 & 1 & & $8 \%$ & 5 & $25.99 \mathrm{~K}$ & $-64.36 \mathrm{~K}$ \\
\hline 1995 & 2 & & $8 \%$ & 5 & $24.88 \mathrm{~K}$ & $-21.41 \mathrm{~K}$ \\
\hline 1996 & 3 & & $8 \%$ & 5 & $23.94 \mathrm{~K}$ & $18.44 \mathrm{~K}$ \\
\hline 1997 & 4 & & $8 \%$ & 5 & $23.17 \mathrm{~K}$ & $55.41 \mathrm{~K}$ \\
\hline 1998 & 5 & & $8 \%$ & 5 & $22.54 \mathrm{~K}$ & $89.71 \mathrm{~K}$ \\
\hline 1999 & 6 & & $8 \%$ & 5 & $22.02 \mathrm{~K}$ & $121.54 \mathrm{~K}$ \\
\hline 2000 & 7 & & $8 \%$ & 5 & $21.61 \mathrm{~K}$ & $151.06 \mathrm{~K}$ \\
\hline 2001 & 8 & & $8 \%$ & 5 & $21.28 \mathrm{~K}$ & $178.45 \mathrm{~K}$ \\
\hline 2002 & 9 & & $8 \%$ & 5 & $21.03 \mathrm{~K}$ & $203.80 \mathrm{~K}$ \\
\hline 2003 & 10 & & $8 \%$ & 5 & $20.84 \mathrm{~K}$ & $227.44 \mathrm{~K}$ \\
\hline 2004 & 11 & & $8 \%$ & 5 & $20.70 \mathrm{~K}$ & $249.32 \mathrm{~K}$ \\
\hline 2005 & 12 & & $8 \%$ & 5 & $20.62 \mathrm{~K}$ & $269.61 \mathrm{~K}$ \\
\hline 2006 & 13 & & $8 \%$ & 5 & $20.57 \mathrm{~K}$ & $288.44 \mathrm{~K}$ \\
\hline 2007 & 14 & & $8 \%$ & 5 & $20.56 \mathrm{~K}$ & $305.90 \mathrm{~K}$ \\
\hline 2008 & 15 & & $8 \%$ & 5 & $20.57 \mathrm{~K}$ & $322.10 \mathrm{~K}$ \\
\hline 2009 & 16 & & $8 \%$ & 5 & $20.61 \mathrm{~K}$ & $337.14 \mathrm{~K}$ \\
\hline 2010 & 17 & & $8 \%$ & 5 & $20.67 \mathrm{~K}$ & $348.38 \mathrm{~K}$ \\
\hline 2011 & 18 & & $8 \%$ & 5 & $20.74 \mathrm{~K}$ & $358.82 \mathrm{~K}$ \\
\hline 2012 & 19 & & $8 \%$ & 5 & $20.83 K$ & $368.50 \mathrm{~K}$ \\
\hline 2013 & 20 & & $8 \%$ & 5 & $20.93 \mathrm{~K}$ & $377.49 \mathrm{~K}$ \\
\hline 2014 & 21 & & $8 \%$ & 5 & $21.04 \mathrm{~K}$ & $385.83 \mathrm{~K}$ \\
\hline
\end{tabular}

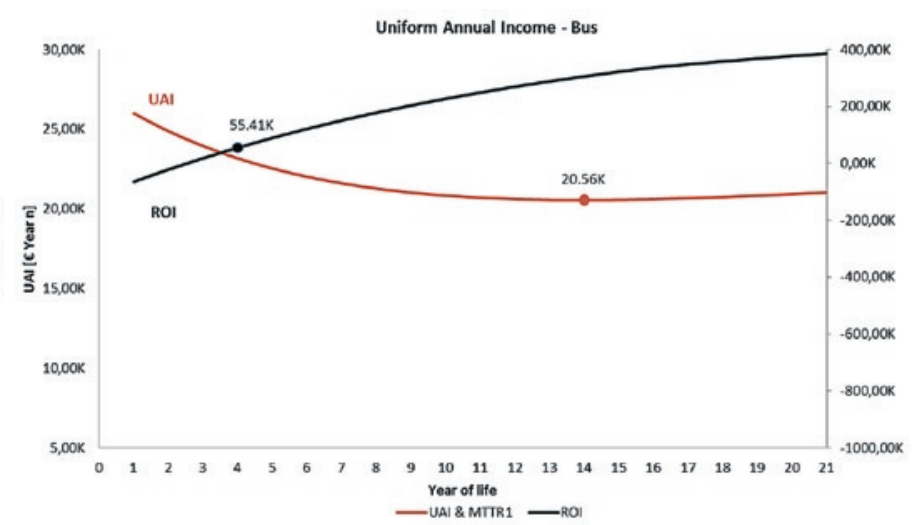

Figure 7.4 - Influence of MTTR=5 on UAI with ROI

Another aspect emphasized in the paper is the importance of implementing condition based maintenance policies; this helps to reduce the costs associated with maintenance and increases availability. To make the point, the paper uses the example of oil analysis.

The paper proposes integrating several methodologies in an econometric global model that supports the decision to replace buses and to calculate the size of the reserve fleet. It validates these methodologies using real data from a bus fleet. The results show the value of the integrated model.

It describes simulations using real data that verify the relations among the maintenance policy, the time of replacement and the dimension of the reserve fleet.

An integrated econometric global model to determine the time of bus replacement and the size of the reserve fleet based on a condition monitoring maintenance model can aid management decision making in these areas. 


\section{References}

1. Amaya E J, Tonaco R, Souza R Q, Álvares A J. Intelligent System Maintenance Based on Condition for Balbina Dam. University of Brasilia, Department of Mechanical Engineering and Mechatronics, Innovation Group in Industrial Automation (GIAI), CEP 70910-900, 8th Congress Engineering Mechanics Ibero Americano, Brasília, DF, Brazil, 2007.

2. André J C S. Probability and Statistics for Engineering. Lisbon: 1st Editions, Lidel - Technical Issues Lda, 2008; ISBN 9789727574773.

3. Aoudia M, Belmokhtar O. Economic impact of maintenance management ineffectiveness of an oil gas company. Journal of Quality in Maintenance Engineering 2008; 14(3): 237-261, https://doi.org/10.1108/13552510810899454.

4. Araujo M S, Bezerra C A. Development of components for stochastic systems for decision support. PUCPR Brazilian, Congress of Computer Science, Software Engineering, Brazil, 2004; 101-107.

5. Assaf Neto A. Corporate finance and value. São Paulo, Atlas, 2005; ISBN: 9788522460144.

6. Assis R, Julião J. Maintenance Management or Asset Management? (Costs over the life cycle). Communication 10th National Congress Maintenance, APMI, Figueira da Foz, Portugal, 2009.

7. Assis R. Decision support in maintenance management of physical assets. Lisbon: 1st Edition, Lidel - Technical issues, Lda, 2010. ISBN: 9789897521126.

8. ASTM International - Standard practice for measuring life-cycle costs of buildings and building system. Annual Book of ASTM Standards: ASTM International West Conshohocken, PA, E 917, 2002; 4(11).

9. BAS PAS 55 - Asset Management: PAS 55-1, Part 1: Specification for the optimized management of physical assets | PAS 55-2, Part 2: Guidelines for the application of PAS 55-1. British Standards, UK, 2008.

10. Beichelt F. A replacement policy based on limiting the cumulative maintenance cost. Department of Statistics and Acturial Science, University of Witwatersrand, Johannesburg, South Africa; International Journal of Quality \& Reliability Management. MCB University Press, 0265671X, 2001; 18(1): 76-83.

11. Bescherer F. Established Life Cycle Concepts in the Business Environment - Introduction and terminology, Laboratory of Industrial Management Report Series, report 1/2005, Helsinki University, 2005; ISBN 951-22-7549.

12. Cabral J S. Organization and Maintenance Management. Lisbon: 6th Edition, Lidel - Technical Issues Lda, 2006 ; ISBN: 9789727574407.

13. Cabrita C P, Cardoso A J M. Concepts and definitions of failure and breakdown in the Portuguese maintenance standards NP EN 13306: 2007 and NP EN 15341: 2009. CISE - Electromechatronic Systems Research Centre, University of Beira Interior, 17 Ibero-American Congress on Maintenance, Cascais, Portugal, 2013.

14. Campello R J G B, Amaral W C. Modelling And Linguistic Knowledge Extration From Systems Using Fuzzy Relation Models, Fuzzy Sets and Systems 2001; 121: 113-126, https://doi.org/10.1016/S0165-0114(99)00175-X.

15, Campos L C D, Vellasco M M B R, Lazo J G L. A stochastic model based on neural networks. PhD thesis, UFJF, Juiz de Fora, Brazil, 2010.

16. Casarotto F N. Investment analysis - financial mathematics, economic engineering, decision making, business strategy. São Paulo, Atlas, 2000; ISBN: 85-224-2572-8.

17. Chena D, Wanga L, Li L. Position computation models for high-speed train based on support vector machine approach. Control and Safety, Beijing Jiaotong University, Beijing 100044, China, 2015, https://doi.org/10.1016/j.asoc.2015.01.017.

18. Couellan N, Jana S, Jorquera T, George J P. Self-adaptive Support Vector Machine: A multi-agent optimisation perspective. Université de Toulouse, UPS IMT, F-31062 Toulouse Cedex 9, France, 2015, https://doi.org/10.1016/j.eswa.2015.01.028.

19. Di J, Hauke L. Optimal fleet utilization and replacement. Transportation Research Part E, 2000; 36(1): 3-30. ISSN: 1366-5545.

20. Durairaj S K, et al. Evaluation of life cycle cost analysis methodologies, corporate Environment Strategy 2002; 9(1): 30-39.

21. Emblemsvag J. Activity-based life-cycle costing. Managerial Auditing Journal 2001; 16(1): 17-27, https://doi. org/10.1108/02686900110363447.

22. Farinha J M T. Maintenance - Terminology and New Management Tools. Lisbon: 1st Edition, Monitor - Design and Publishing, Lda, 2011; ISBN 978-972-9413-82-7.

23. Feldens A G, Muller C J, Filomena T P, Neto F J K, Castro A S, Anzanello M J. Policy Assessment and Fleet Replacement by Means of Model Multicriteria Adoption. Porto Alegre, Brazil, 2010; ISSN 1980-4814.

24. Figueiredo L M J. Multicriteria model to support the replacement of hospital medical equipment, PhD thesis, IST, Lisbon, Portugal, 2009.

25. Francis K N, Leung and Ada, Cheng L M. Determining replacement policies for bus engines. City University of Hong Kong, Hong Kong; International Journal of Quality \& Reliability Management, MCB University Press, 0265-671X, 2000; 17 (7): 771-783.

26. Gurney K. An introduction to neural networks, London, UCL Press, 1997; ISBN: 1857285034, https://doi.org/10.4324/9780203451519.

27. Huang J, Yao M. On the coordination of maintenance scheduling for transportation fleets of many branches of a logistic service provider. Ling Tung University1 Ling Tung Road, Nantun, Taichung 408, Taiwan, ROC, 2008, https://doi.org/10.1016/j.camwa.2008.01.037.

28. ISO 55000:2014 - Asset management - Overview, principles and terminology; ISO 55001:2014 - Asset management - Management systems - Requirements; ISO 55002:2014 - Asset management - Management systems - Guidelines for the application of ISO 55001, 2014.

29. Jennifer L R, Joseph C H. Equipment replacement under continuous and discontinuous technological change. IMA Journal of Management Mathematics 2005; 16 (1): 23-36, https://doi.org/10.1093/imaman/dph027.

30. Khasnabis S, Alsaidi E, Ellis R. Optimal allocation of resources to meet transit fleet requirements. Journal of Transportation Engineering 2002; 128 (6): 509-518, https://doi.org/10.1061/(ASCE)0733-947X(2002)128:6(509).

31. Korpi E, Ala-Risku T. Life cycle costing: a review of public case studies. Managerial Auditing Journal 2008; 23 (3): 240-261, https://doi. org/10.1108/02686900810857703.

32. Lindholm A, Suomala P. The possibilities of Life Cycle Costing in Outsourcing Decision Making. Frontiers of E-Business Research 2004; $226-241$.

33. Luna I, Ballini R, Soares S. Identification technique of linear and nonlinear time series. Magazine Automation and Control 2006 ; 17 (3): 245-256.

34. Makridakis S, Wheelwright S, Hyndman R F. Forecasting -Methods and Applications. New York: John Wiley \& Sons, 1998; ISBN 0-471-53233-9.

35. Marco A R, Angelo A D, Leizer S, Silvio A B V. The use of Bayesian networks in the decision making process interventions in equipment. Industrial Engineering Program, Federal University of Bahia, Polytechnic School, XVIII Brazilian Congress Auto / 12 to 16 September 2010 
Federation, 40210-630, Salvador, Brazil, 2010; 5058-5064.

36. Motta R R, Calôba G M. Investment analysis: decision making in industrial projects. São Paulo: Atlas, 2002; ISBN: 9788522430796.

37. Múller D. Stochastic processes and applications, Collection Economic volume - 2nd Series off Financial Law and Tax. Almedina, 2007.

38. Natali H, Yuri Y. Optimal equipment replacement without paradoxes: A continuous analysis. Operations Research Letters 2007; 35 (2): 245-250, https://doi.org/10.1016/j.orl.2006.03.001.

39. Oliveira J A N. Economic Engineering - an approach to investment decisions. São Paulo: McGraw-Hill Brazil, 1982.

40. Pinar K, Hartman J. Case Study: Bus Fleet Replacement. The Engineering Economist 2004; 49 (3): 253-278, https://doi. org/10.1080/00137910490498951.

41. Pooyan N, Shahbazian M, Salahshoor K, Hadian M. Simultaneous Fault Diagnosis using multi class support vector machine in a Dew Point process. Department of Instrumentation and Automation, Petroleum University of Technology, Ahwaz, Iran, 2015, https://doi.org/10.1016/j. jngse.2015.01.043.

42. Portuguese NP EN 15341: 2009 - Maintenance - performance indicators of maintenance (KPI), 2009.

43. Raposo H D N, Farinha J T, Oliveira R, Ferreira L A, André J. Time Replacement Optimization Models for Urban Transportation Buses with Indexation to Fleet Reserve. MPMM - Maintenance Performance Measurement and Management; Coimbra, Portugal, 2014; 1(1): ISBN 978-972-8954-43-7, https://doi.org/10.14195/978-972-8954-42-2 7.

44. Romaniuk M. On simulation of maintenance costs for water distribution system with fuzzy parameters. Eksploatacja i Niezawodnosc Maintenance and Reliability 2016; 18 (4): 514-527, https://doi.org/10.17531/ein.2016.4.6.

45. Scarf P A, Bouamra O A. Capital equipment replacement model for a fleet with variable size. Centre for OR and Applied Statistics, University of Salford, UK, Journal of Quality in Maintenance Engineering, C MCB University Press, 1355-251, 1999; 5 (1): 40-49, https:// doi.org/10.1108/13552519910257050.

46. Seabra J, Graça B. Analysis of oils and greases in service. Proceedings of the Fifth National Congress of Industrial Maintenance - APMI, Figueira da Foz, 1996.

47. Simões A S. Conditional maintenance to Pollutant Emissions in Urban Buses, Using Degradation Prediction Models Based on the technology of vehicles and the Operating Conditions; PhD final thesis. Instituto Superior Técnico, 2011.

48. Tsoukalas L H, Uhrig R E. Fuzzy and neural approaches in engineering, New York: John Wiley, 1996. ISBN: 0471160032.

49. Vey I H, Rosa R M. Fleet replacement in municipal passenger transportation company: a case study. Federal University of Santa Maria, Electronic Accounting Journal 2004; 1 (1): 150-173.

50. Vujanovic D, Momc `ilovic V, Bojovic N, Papic V. Evaluation of vehicle fleet maintenance management indicators by application of DEMATEL and ANP. University of Belgrade, Faculty of Transport and Traffic Engineering, Vojvode Stepe 305, Belgrade, Serbia, 2012, https://doi.org/10.1016/j.eswa.2012.02.159.

51. Wijaya A R, Lundberg J, Kumar U. Robust-optimum multi-attribute age-based replacement policy. Journal of Quality in Maintenance Engineering 2012; 18 (3): 325-343.

52. William G Sullivan, Thomas N McDonald, Eileen M Van Aken. Robotics and Computer Integrated Manufacturing 2002; 18 (3-4): 255-265, https://doi.org/10.1016/S0736-5845(02)00016-9.

53. Yager R R, Zadeh L A. Introduction to fuzzy logic applications-An in intelligent systems Boston, Kluwer Academic, Publishers, 1992.

54. Zhao H. A chaotic time series prediction based on neural network: Evidence from the Shanghai composite index in China. Test and Measurement 2009; 2 (1): 382 -385.

55. Zohrul, Kabir A B M. Evaluation of overhaul/replacement policy for a fleet of buses. Journal of Quality in Maintenance Engineering 1996; 2 (3): $49-59$,https://doi.org/10.1108/13552519610130440.

\section{Hugo RAPOSO}

CEMMPRE - Centre for Mechanical Engineering, Materials and Processes. University of Coimbra, 3030-788 Coimbra, Portugal

\section{José Torres FARINHA}

CEMMPRE - Centre for Mechanical Engineering, Materials and Processes.

University of Coimbra, 3030-788 Coimbra, Portugal

and

IPC - Polytechnic Institute of Coimbra.

3000-271 Coimbra, Portugal

\section{Luís FERREIRA}

UP - University of Porto

4200-465 Porto, Portugal

\section{Diego GALAR}

Lulea University of Technology, Sweden

Division of Operation and Maintenance Engineering, Department of Civil, Environmental and Natural Resources Engineering, 971- 87 Luleå, Sweden

E-mails: hugrap@gmail.com, torres.farinha@dem.uc.pt, Iferreir@fe.up.pt, diego.galar@ltu.se 